\title{
Short communication: Mammary gland tight junction permeability after parturition is greater in dairy cows with elevated circulating serotonin concentrations
}

\author{
E. C. Kessler, ${ }^{1 *}$ S. K. Wall, ${ }^{1}$ L. L. Hernandez, ${ }^{2}$ J. J. Gross, ${ }^{1}$ and R. M. Bruckmaier ${ }^{1}$ \\ ${ }^{1}$ Veterinary Physiology, Vetsuisse Faculty, University of Bern, CH-3012 Bern, Switzerland \\ ${ }^{2}$ Department of Dairy Science, University of Wisconsin, Madison 53706
}

\section{ABSTRACT}

After parturition, the start of copious milk production in dairy cows requires the closure of tight junctions (TJ) to form the blood-milk barrier and prevent paracellular transfer of blood constituents into milk [e.g., lactate dehydrogenase (LDH) and serum albumin (SA)] and vice versa [e.g., appearance of $\alpha$-lactalbumin $(\alpha-\mathrm{LA})$ in blood]. Serotonin $(5-\mathrm{HT})$ has been demonstrated to alter tight junction permeability in the mammary gland. The present study investigated individual differences of TJ permeability of mammary epithelium at the beginning of lactation in relation to circulating 5-HT in dairy cows. Blood and milk samples were obtained from 11 multiparous Holstein dairy cows for the first time at $4 \mathrm{~h}$ after parturition, at the following 5 milkings, and at the evening milkings on d 5, 8, 10, and 14 of lactation. Retrospectively, cows were split into 2 groups according to their calculated areas under the curve of serum 5-HT during the entire experimental period: a high-serum 5-HT (HSS) group (5 cows) and a low-serum 5-HT (LSS) group (6 cows). The areas under the curve of serum 5-HT concentrations over the 324 -h experimental period were $62 \pm 2 \times 10^{3} \mathrm{ng} / \mathrm{mL}$ in HSS and $25 \pm 5 \times 10^{3} \mathrm{ng} / \mathrm{mL}$ in LSS. Plasma $\alpha$-LA concentration was greater in LSS than in HSS cows at the first milking, but no difference between groups was found from the second to sixth milking. Yield of $\alpha-\mathrm{LA}$ in milk was lower in HSS than in LSS during the first 6 milkings postpartum, especially in colostrum. Concentrations of $\alpha-L A, \operatorname{Ig} G_{1}$, and $\operatorname{IgG}_{2}$ in milk did not differ between groups during the entire experiment except for higher IgG observed in LSS than in HSS at the second milking and for higher $\mathrm{IgG}_{2}$ found in HSS compared with LSS on d 5. In contrast, SA concentrations and LDH activity in milk were lower in LSS compared with HSS cows during the first 6 milkings postpartum,

Received August 11, 2018.

Accepted October 8, 2018.

*Corresponding author: evelyne.kessler@vetsuisse.unibe.ch particularly in colostrum. Milk somatic cell count was higher in HSS than in LSS throughout the study. Higher circulating 5-HT concentrations were associated with an increased transfer of the paracellularly transported SA, LDH, and somatic cell count, especially at the first milking, suggesting that 5-HT affects TJ permeability during closure of the blood-milk barrier at the onset of lactation. Furthermore, higher serum 5-HT concentrations were associated with a lower $\alpha$-LA yield in milk. A consistent relationship with serum 5-HT concentrations was neither observed for the transfer of $\mathrm{IgG}_{2}$ nor the primarily transcellular transport of $\mathrm{IgG}_{1}$ during the first milkings after parturition.

Key words: serotonin, tight junctions, onset of lactation, blood-milk barrier, dairy cow

\section{Short Communication}

An intact blood-milk barrier is critical for the function of the lactating mammary gland by preventing uncontrolled exchange of constituents between blood and milk. The paracellular transfer of ions and molecules between blood and milk is prevented by the junctional complex, consisting of desmosomes, adherens junctions, and tight junctions (TJ), which act as a seal between adjacent epithelial cells and coordinates the cell-cell adherence and their interactions (Chiba et al., 2008; Stelwagen and Singh, 2014). The blood-milk barrier and TJ are leaky before parturition, which allows, along with active transport mechanisms, the transfer of even larger molecules such as soluble immune factors, antibodies, and blood cells into colostrum (Stelwagen et al., 2009; Stelwagen and Singh, 2014). Hormonal changes occurring around parturition (e.g., temporarily peaking concentrations of prolactin and glucocorticoids) mediate the closure of TJ, which become impermeable to a further exchange of blood and milk components (Nguyen and Neville, 1998; Wall et al., 2015). In addition, the formation of intact TJ at the beginning of lactation is essential to ensure the start of copious milk production (Stelwagen and Singh, 2014). 
Serotonin (5-HT) was shown to alter TJ permeability in a concentration and time-dependent manner in mouse, human, and bovine mammary epithelial cells (Stull et al., 2007; Pai and Horseman, 2008; Hernandez et al., 2011). Dairy cows that received an intramammary infusion of a selective 5-HT reuptake inhibitor, which increases the cellular exposure to 5-HT, at dry off exhibited disassembly of TJ (Hernandez et al., 2011). As the serotonergic system is involved in the regulation of milk yield during established lactation and in mammary gland involution in late lactation (Collier et al., 2012), this suggests a potential direct role for 5-HT at the beginning of lactation, manifesting in a potential alteration of TJ permeability.

In the present study, we aimed at investigating the association of the individual variation in cows' TJ permeability during the period of blood-milk barrier closure at the onset of lactation with their respective circulating 5-HT concentrations. We hypothesized that TJ permeability increased during the first days after parturition in cows with higher circulating 5-HT concentrations in blood.

The present experiment followed the Swiss law of animal protection [Swiss Federal Act on Animal Protection (LPA 2005; January 2011)] and was approved by the committee of animal experiments of the Canton of Fribourg, Switzerland (permit no. 2013-01-FR). This experiment initially involved 12 multiparous Holstein dairy cows from parturition until d 14 of lactation. One cow was removed from the experiment due to a nondetected udder problem in the colostral period. The final data set included 11 cows (parity $=3.7 \pm 0.9$; milk yield in the previous 305-d lactation $=8,940 \pm 1,791$ $\mathrm{kg}$; mean $\pm \mathrm{SD}$ ). Cows were housed in a freestall barn except during parturition, when they were moved to a straw-bedded calving pen. Before parturition, animals received $0.5 \mathrm{~kg} / \mathrm{d}$ of a vitamin-mineral premix for dry cows that switched immediately to $0.3 \mathrm{~kg} / \mathrm{d}$ of a premix designed for lactating dairy cows after calving. Premixes were prepared at the Federal Research Station Agroscope (Posieux, Switzerland). The dry cow premix contained 2,7 , and $13 \mathrm{~g} / \mathrm{kg}$ of $\mathrm{Ca}, \mathrm{P}$, and $\mathrm{Mg}$, respectively, and 180,200 and $14,400 \mathrm{IU} / \mathrm{kg}$ of vitamin $\mathrm{A}$ and $\mathrm{D}_{3}$, respectively, as well as $1,170 \mathrm{mg} / \mathrm{kg}$ of vitamin $\mathrm{E}$; the premix for lactating cow contained 104, 65, and 25 $\mathrm{g} / \mathrm{kg}$ of Ca, $\mathrm{P}$, and $\mathrm{Mg}$, respectively, 200,000 and 16,000 $\mathrm{IU} / \mathrm{kg}$ of vitamin $\mathrm{A}$ and $\mathrm{D}_{3}$, respectively, and $1,300 \mathrm{mg} /$ $\mathrm{kg}$ of vitamin E. Cows had free access to water, hay, and fresh herbage. Calves were removed immediately after calving to avoid suckling from their dams.

Blood and milk samples were initially taken $4 \mathrm{~h}$ after parturition. Afterward, cows were regularly milked twice daily (0530 and $1630 \mathrm{~h}$ ) and samples (blood and milk) were taken at the subsequent 5 milkings and again at the afternoon milkings on $\mathrm{d} 5,8,10$, and 14 of lactation. Blood samples were obtained from the jugular vein 20 min after the start of milking (1 EDTA-coated tube and 1 serum tube containing a clot activator; Vacuette, Greiner Bio One, Kremsmünster, Austria). Serum was allowed to clot at room temperature for 30 min, whereas EDTA blood was immediately put on wet ice. Thereafter, samples were centrifuged at $2,500 \times g\left(20 \mathrm{~min}\right.$ at $\left.4^{\circ} \mathrm{C}\right)$ to obtain plasma and serum. Until analysis, serum aliquots were stored at $-80^{\circ} \mathrm{C}$ and plasma and milk samples at $-20^{\circ} \mathrm{C}$.

Serum was analyzed for 5-HT with a commercial ELISA kit (Fast Track, \#BA E-8900; Rocky Mountain Diagnostics, Colorado Springs, CO) according to the manufacturers' instructions (https://www.biocompare .com/9956-Assay-Kit/980013-Serotonin-ELISA-Fast -Track/). Intra- and interassay coefficients of variation for 5 -HT were $<5$ and $<15 \%$, respectively. Concentrations of $\alpha-\mathrm{LA}$ in plasma and milk were assessed with an ELISA using a bovine-specific commercial kit (E10128, Bethyl Laboratories, Montgomery, TX) according to the manufacturer's instructions (https://www.bethyl .com/product/pdf/E10-128_26.pdf). Plasma and milk samples were diluted in wash buffer to fall in the range of the standard curve. The inter- and intra-assay coefficients of variation were 6.32 and $3.69 \%$ for $\alpha$-LA in plasma and 2.95 and $3.08 \%$ for $\alpha-\mathrm{LA}$ in milk, respectively. Concentrations of serum albumin (SA) in milk were analyzed by ELISA using a bovine-specific commercial ELISA kit (E10-113; Bethyl Laboratories, Montgomery, TX, https://www.bethyl.com/product/ pdf/E10-113_37.pdf) after being diluted in range of the standards in wash buffer. The inter- and intraassay coefficients of variation for SA in milk were 4.87 and $4.14 \%$, respectively. Measurements of milk $\operatorname{IgG}_{1}$ and $\mathrm{IgG}_{2}$ concentrations were performed using bovinespecific commercial ELISA kits (E10-116 for $\operatorname{IgG}_{1}$ and E10-117 for $\mathrm{IgG}_{2}$; Bethyl Laboratories) according to manufacturer's instructions with slight adaptations (Lehmann et al., 2013). The inter- and intra-assay coefficients of variation were 3.5 and $13.8 \%$ for $\operatorname{IgG}_{1}$ and 3.6 and $8.6 \%$ for $\operatorname{IgG}_{2}$ in milk, respectively. The activity of lactate dehydrogenase $(\mathbf{L D H})$ was measured in milk serum with a commercial colorimetric kit (LDH IFCC, Axon-Lab AG, Baden, Switzerland) according to the manufacturer's instructions (https://ch.axonlab .com/de/praxis/humanmedizin/klinische-chemie/ reagenzien/4439/axon-ldh-ifcc). Somatic cell count in milk was determined with a DeLaval cell counter (DCC, DeLaval, Tumba, Sweden). Colostrum and milk samples were diluted when the viscosity was too high or if the cell count exceeded $3 \times 10^{6} / \mathrm{mL}$, as described in Wall et al. (2015). More details about the methods used for the measurement of $\alpha$-LA in plasma and milk, 
SA, immunoglobulins, LDH activity, and SCC in milk are given elsewhere (Wall et al., 2015).

Individual serum 5-HT profiles during the experimental period (first $14 \mathrm{~d}$ of lactation) were assessed, and the area under the curve (AUC) was calculated applying the trapezoidal rule. Thereafter, the median of individually estimated 5-HT AUC served for the retrospective assignment of cows to 1 of 2 groups. As the median was lower than the arithmetic average of all 5-HT AUC, the median 5-HT AUC was allocated to the lower serum 5-HT group. At a cutoff AUC value of higher or lower than $38 \times 10^{3} \mathrm{ng} / \mathrm{mL}(\times 324 \mathrm{~h}), 5$ cows were assigned to the high-serum 5-HT [HSS; AUC of 5 -HT $\left.(\mathrm{ng} / \mathrm{mL} \times 324 \mathrm{~h})=62 \pm 2 \times 10^{3}\right)$ and 6 cows to the low-serum 5 -HT group [LSS; AUC of 5 -HT $(\mathrm{ng} / \mathrm{mL}$ $\left.\times 324 \mathrm{~h})=25 \pm 5 \times 10^{3}\right]$.

All data presented here are means \pm standard error of the means, except where denoted as standard deviation. The statistical software package SAS (version 9.4, SAS Institute Inc., Cary, NC) was used for statistical analysis. Data were assessed with the UNIVARIATE procedure for normality. Associations of high and low serum 5-HT concentrations with blood $(\alpha-\mathrm{LA})$ and milk (proteins, LDH activity, and SCC) parameters were assessed using the MIXED procedure with time, group, and the time $\times$ group interaction as fixed effects and the individual cow as random subject. Differences between groups (HSS and LSS) from the first to the sixth milking and from d 5 until 14 of lactation were separately estimated with the Bonferroni-corrected $t$ test. Significant effects were considered at $P<0.05$.

Grouping according to the AUC of 5 -HT serum concentrations of the first 2 wk of lactation resulted in consistently higher serum 5-HT concentrations in HSS compared with LSS during the first 6 milkings and from d 5 until 14 of lactation $(P<0.01)$. The pattern of individual serum 5-HT concentrations in cows classified HSS or LSS was recently published with regard to lactational performance and metabolic status (Kessler et al., 2018). Plasma $\alpha$-LA concentrations were highest at the first milking and decreased thereafter until the sixth milking (Figure 1A). From d 5 until 14 postpartum, concentrations of $\alpha-\mathrm{LA}$ in plasma remained at similar levels. Plasma $\alpha$-LA concentrations were higher in LSS than in HSS at the first milking $(P<0.05)$, whereas from the second to the sixth milking postpartum no differences between groups were detected. In contrast, from d 5 until 14 of lactation, plasma $\alpha$-LA concentrations were higher in HSS than in LSS $(P<$ $0.05)$. Milk $\alpha$-LA concentrations were highest directly after calving, decreased from the third milking until d 5 of lactation, and remained at a steady concentration until d 14 postpartum (Figure 1B). Milk $\alpha$-LA concentrations were not related to 5 - $\mathrm{HT}$ grouping $(P$
$=0.60$ and $P=0.67$ for milking 1 to 6 and $\mathrm{d} 5$ to 14 postpartum, respectively). The amount of $\alpha$-LA in milk decreased from the first to the second milking, subsequently increased until the fifth milking, and remained thereafter on similar levels (Figure 1C). Milk $\alpha$-LA yield was lower in HSS compared with LSS at the first milking and also until the sixth milking $(P<$ 0.001 and $P=0.01$, respectively). From d 5 until 14 of lactation, $\alpha$-LA yield in milk did not differ between groups $(P=0.47)$. The highest LDH activity and milk SA concentrations were at the first milking, with higher concentrations being found in the HSS compared with LSS $(P<0.001$ for LDH activity and $P<0.01$ for SA concentration; Figures $1 \mathrm{D}$ and $1 \mathrm{E}$ ). Thereafter, LDH activity and SA concentration in milk decreased until the fifth milking and remained at a low level from $\mathrm{d}$ 5 to 14 of lactation. Increased SA concentrations and LDH activity in milk were detected in HSS compared with LSS from the first to the sixth milking $(P<0.01$ for LDH activity and $P<0.05$ for SA concentration). No differences in milk SA content and LDH activity were detected between groups from d 5 to $14(P=0.22$ and $P=0.46$, respectively).

In both groups, concentrations of $\operatorname{IgG}_{1}$ and $\operatorname{IgG}_{2}$ in milk decreased rapidly from the first to the third milking and remained at a low concentration until the end of the experiment (Figures 2A and 2B). Grouping according to serum 5 -HT concentrations did not reveal differences in concentrations of $\operatorname{IgG}_{1}$ and $\operatorname{IgG}_{2}$ in milk throughout the experiment, except for higher IgG detected in LSS at the second milking and for higher $\mathrm{IgG}_{2}$ observed in HSS compared with LSS on d 5 . In all cows, milk SCC was highest at the first milking and steadily decreased thereafter, reaching lowest values on d 14 postpartum (Figure 3). Grouping by circulating 5-HT concentrations showed an increased milk SCC in HSS compared with LSS cows during the entire study $(P<0.01)$.

Downregulation of milk protein gene expression, such as $\alpha-L A$, and loss of TJ integrity were identified as underlying mechanisms for 5-HT during mammary gland involution (Hernandez et al., 2008, 2011). $\alpha$-Lactalbumin is crucial for the biosynthesis of lactose, representing the main osmole in milk. In mammary epithelial cells treated in vitro with supraphysiological concentrations of 5-HT, $\alpha$-LA gene expression was reduced (Hernandez et al., 2008, 2011). Therefore, our finding of a lower $\alpha$-LA yield in milk of cows with higher circulating 5-HT concentrations confirms the results of the aforementioned in vitro conducted experiments. The previously reported lower milk yield in HSS cows (Kessler et al., 2018) with concomitantly reduced $\alpha$-LA yield, and vice-versa for LSS cows, explains the lack of differences regarding $\alpha$-LA concentration in milk. 

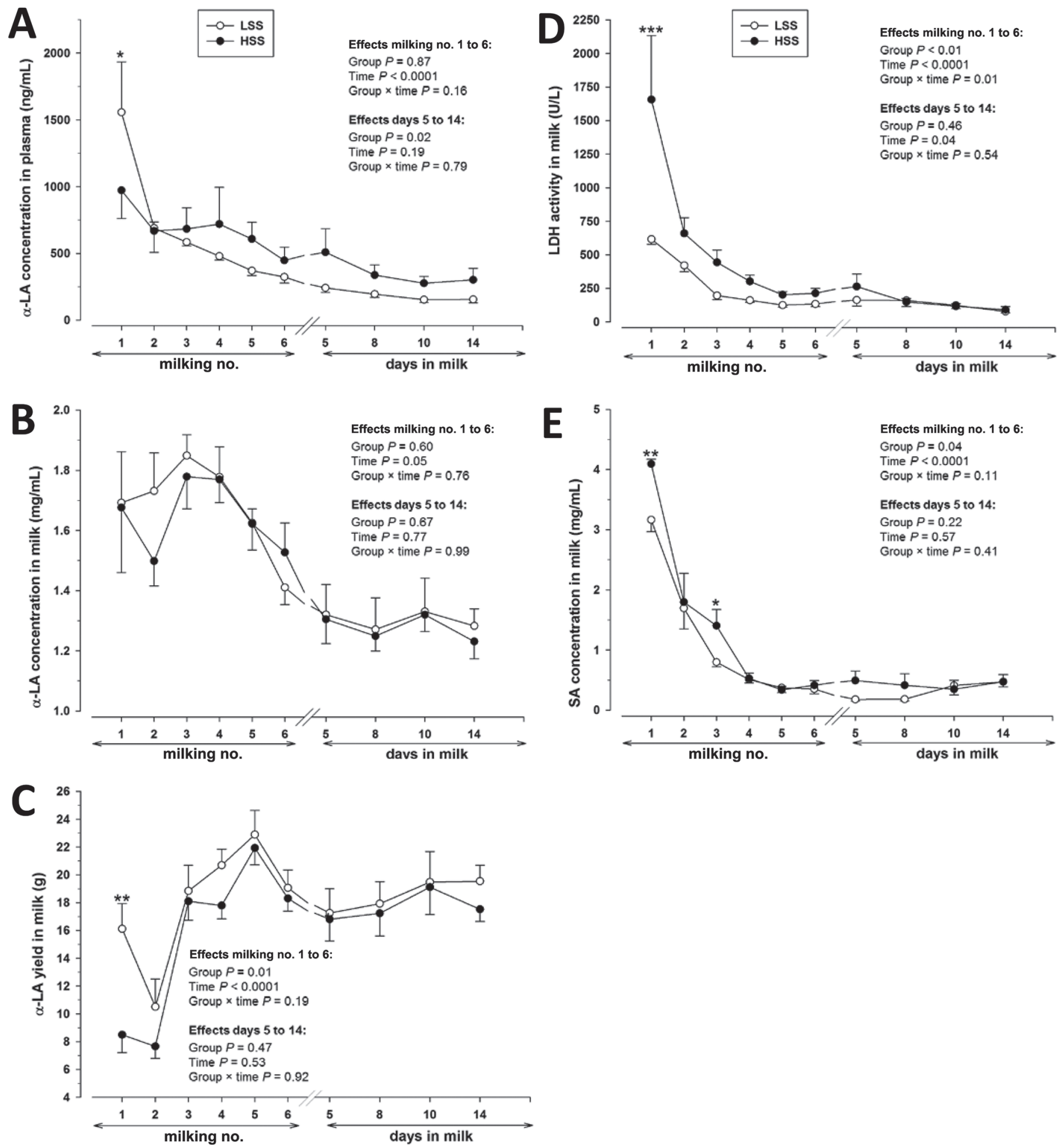

Figure 1. Plasma concentrations of $\alpha$-LA (A), milk concentrations of $\alpha$-LA (B), $\alpha$-LA yield in milk (C), lactate dehydrogenase activity (LDH; D), and serum albumin (SA; E) in cows with low serum serotonin (LSS) and high serum serotonin (HSS) at the first 6 consecutive milkings after parturition and on d 5,8,10, and 14 of lactation. Differences for plasma and milk $\alpha$-LA concentrations, $\alpha$-LA yield in milk, LDH activity, and SA concentrations in milk between HSS and LSS at individual sampling events are indicated by ${ }^{* * *} P<0.001, * * P<0.01$, and ${ }^{*} P$ $<0.05$. Data are presented as means \pm SEM. 
Throughout lactation, when the blood-milk barrier and TJ are commonly intact, the milk-specific protein $\alpha$-LA is only measurable at marginal levels in blood (Stelwagen et al., 1997; Wall et al., 2015). Therefore, the appearance of $\alpha$-LA in the bloodstream indicates a loss of TJ integrity. Reciprocally, elevated concentrations of blood-derived factors in milk (e.g., LDH and SA) are markers for mammary TJ leakiness (Stelwagen et al., 1994; Lehmann et al., 2013). In this context, the decreasing concentrations of LDH and SA in milk and those of $\alpha-\mathrm{LA}$ in plasma reflect the change of TJ functionality status from permeable to impermeable during the first milkings after calving (McFadden et
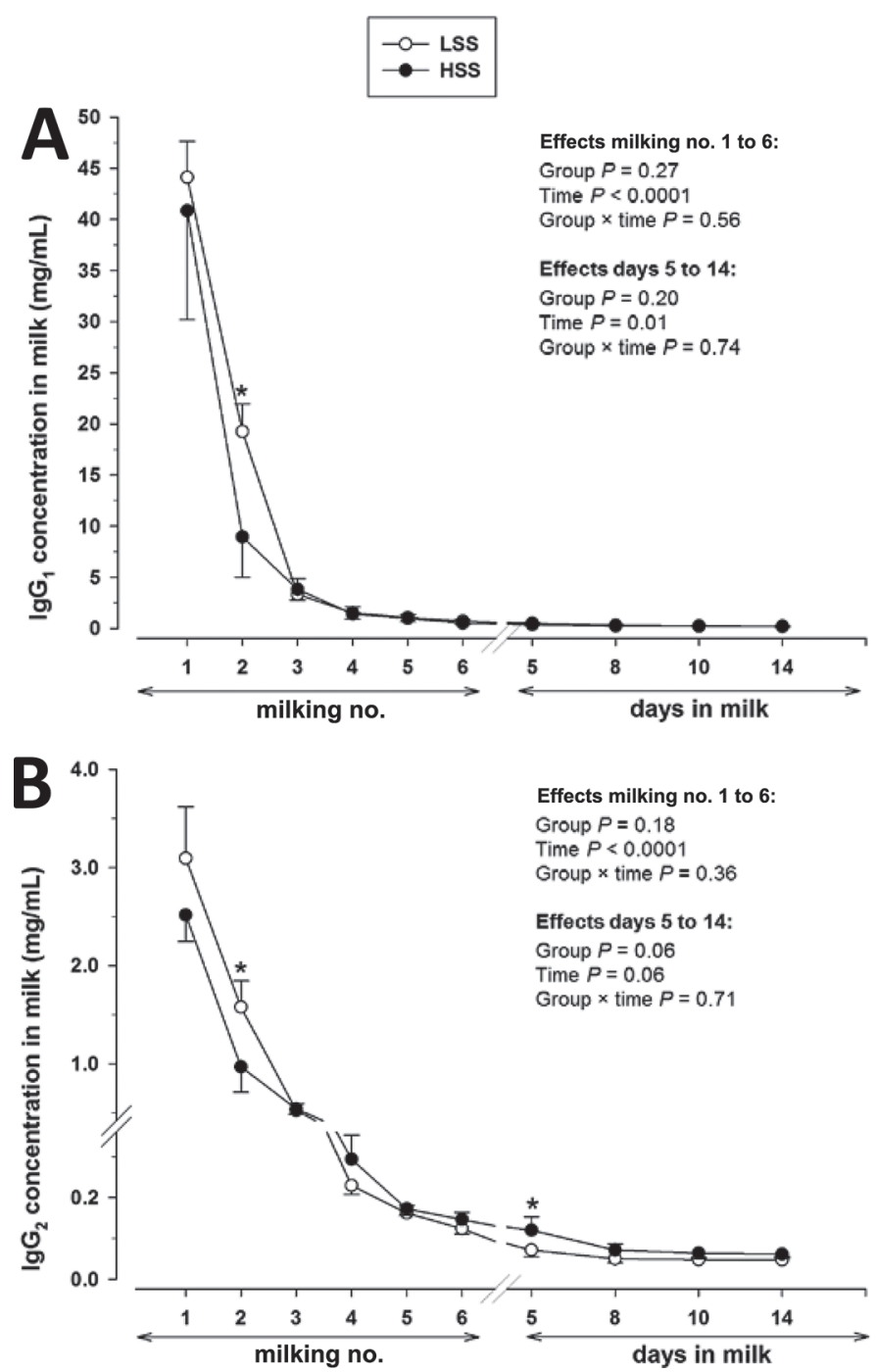

Figure 2. Milk concentrations of $\operatorname{IgG}_{1}$ (A) and $\operatorname{IgG}_{2}$ (B) of cows with low serum serotonin (LSS) and high serum serotonin (HSS) at the first 6 consecutive milkings after parturition and on $\mathrm{d} 5,8,10$, and 14 of lactation. Differences for milk $\operatorname{IgG}_{1}$ and $\operatorname{IgG}_{2}$ concentrations between HSS and LSS at individual sampling events are indicated by ${ }^{*} P<0.05$. Data are presented as means \pm SEM al., 1987; Levieux and Ollier, 1999; Wall et al., 2015). Furthermore, Wall et al. (2015) demonstrated that the blood-specific SA and LDH and milk-derived $\alpha$-LA are exchanged between these compartments via paracellular pathways. In our study, SA and LDH were greater in colostrum of HSS cows and also during the decline occurring at the first milkings, whereas $\alpha$-LA concentrations in blood were higher in LSS than in HSS cows only at the first milking. The latter result might be explained by the reduced $\alpha$-LA yield observed in HSS cows, especially at the first milking, possibly masking a higher transfer of $\alpha$-LA from milk into blood in HSS cows related to an increased TJ permeability. Hence, different physiological levels of circulating 5-HT might be associated with a differential paracellular transport pattern of $\alpha$-LA, SA, and LDH during TJ closure at the start of lactation.

Immunoglobulins are an essential bioactive component of colostrum, as they provide passive immunization for the ruminant offspring. The transfer of maternal IgG into colostrum is maintained for at least a few hours after parturition and appears to happen in a manner widely independent of changes in progesterone and prolactin (Gross et al., 2014; Baumrucker et al., 2016). Furthermore, the transport of $\mathrm{IgG}_{1}$ into colostrum occurs primarily via transcytosis, whereas $\operatorname{IgG}_{2}$ is supposed to pass paracellularly (Baumrucker and Bruckmaier, 2014; Wall et al., 2015). Although evidence is growing for a role of 5 -HT signaling in antibody producing B lymphocytes (Ahern, 2011), we did not observe any variation in colostral IgG concentrations in relation to

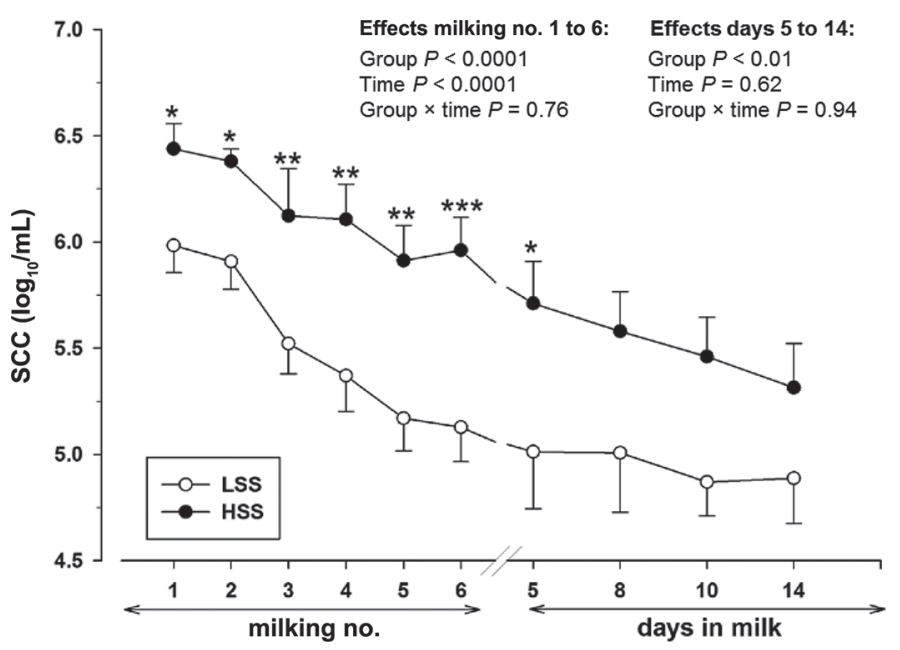

Figure 3. Somatic cell count in milk of cows with low serum serotonin (LSS) and high serum serotonin (HSS) at the first 6 consecutive milkings after parturition and on d 5, 8, 10, and 14 of lactation. Differences for milk SCC between HSS and LSS at individual sampling events are indicated by ${ }^{* * *} P<0.001,{ }^{* *} P<0.01$, and ${ }^{*} P<0.05$. Data are presented as means \pm SEM 
different levels of circulating 5-HT. Our results are in accordance with the study of Hernández-Castellano et al. (2017), who demonstrated that a prepartum infusion of a 5-HT precursor elevating circulating 5-HT concentrations in cows did not affect IgG concentrations in colostrum. As $\operatorname{IgG}_{2}$ are thought to be transported into milk paracellularly, and due to the higher concentrations of the similarly transferred $\mathrm{LDH}$ and $\mathrm{SA}$ observed in HSS cows, we assumed increased $\operatorname{IgG}_{2}$ concentrations in cows with higher circulating 5-HT during the first milkings postpartum. However, different serum 5-HT concentrations did not result in striking differences in $\operatorname{IgG}_{2}$ concentrations in milk during closure of TJ, except at the second milking. In contrast to our expectations, we observed lower $\operatorname{IgG}_{2}$, and also $\operatorname{IgG}_{1}$, in HSS cows at this time point. Thus, we speculated that 5 -HT is not significantly involved in the regulation of transcellular trafficking of $\operatorname{IgG}$ in the peripartal period. Furthermore, the lack of consistent group differences in the passive transfer of $\mathrm{IgG}_{2}$ into milk during TJ closure might be explained by another potential alternative transport mechanism, as suggested by Samarütel et al. (2016), which is not controlled by 5-HT.

Milk SCC is commonly elevated in colostrum and in milk up to 2 wk after parturition, independent of the potential presence of IMI (Natzke et al., 1972; Dohoo and Meek, 1982). In the bovine mammary gland, the first line of defense against invading pathogens is represented by leukocytes (e.g., neutrophils; Burvenich et al., 1994; Sordillo et al., 1997), whereby their number and activity determine the duration and severity of a mastitis (Sordillo et al., 2009). With reference to the present study, several reports state an involvement of 5-HT in functional aspects of the immune system (Mössner and Lesch, 1998; Ahern, 2011). Therefore, an increased presence of immune cells in the udder of cows with higher circulating 5-HT might be beneficial, especially during the peripartal period when cows are more prone to mastitis (Sordillo et al., 2009). In early lactation, apoptosis and shedding of mammary epithelial cells into milk occur at an important rate (Capuco et al., 2001; Annen et al., 2007). Serotonin was shown to induce cell shedding and intraepithelial apoptosis in vitro and in vivo (Pai and Horseman, 2011). Thus, an increased number of milk epithelial cells derived from augmented cell shedding and apoptosis might contribute to the overall higher SCC found in the milk of cows with higher circulating 5 -HT.

During closure of the blood-milk barrier, including TJ at the onset of lactation and especially at the first milking, higher circulating serum 5-HT concentrations were related to an increased paracellular permeability for SA and LDH, as well as to a reduced amount of $\alpha$-LA secreted into milk. In contrast, the transcytosis of $\operatorname{IgG}_{1}$ and the transfer of $\operatorname{IgG}_{2}$ into milk were not consistently associated with different circulating 5-HT concentrations. The direct effect of 5 -HT on the mammary tissue is closely reflected by differences in SCC content.

\section{REFERENCES}

Ahern, G. P. 2011. 5-HT and the immune system. Curr. Opin. Pharmacol. 11:29-33. https://doi.org/10.1016/j.coph.2011.02.004.

Annen, E. L., A. C. Fitzgerald, P. C. Gentry, M. A. McGuire, A. V. Capuco, L. H. Baumgard, and R. J. Collier. 2007. Effect of continuous milking and bovine somatotropin supplementation on mammary epithelial cell turnover. J. Dairy Sci. 90:165-183. https: //doi.org/10.3168/jds.S0022-0302(07)72618-8.

Baumrucker, C. R., and R. M. Bruckmaier. 2014. Colostrogenesis: IgG1 transcytosis mechanisms. J. Mammary Gland Biol. Neoplasia 19:103-117. https://doi.org/10.1007/s10911-013-9313-5.

Baumrucker, C. R., C. D. Dechow, A. L. Macrina, J. J. Gross, and R. M. Bruckmaier. 2016. Mammary immunoglobulin transfer rates following prepartum milking. J. Dairy Sci. 99:9254-9262. https:// doi.org/10.3168/jds.2016-11370.

Burvenich, C., M. J. Paape, A. W. Hill, A. J. Guidry, R. H. Miller, R. Heyneman, W. D. Kremer, and A. Brand. 1994. Role of the neutrophil leucocyte in the local and systemic reactions during experimentally induced $E$. coli mastitis in cows immediately after calving. Vet. Q. 16:45-50. https://doi.org/10.1080/01652176.1994 .9694482 .

Capuco, A. V., D. L. Wood, R. Baldwin, K. Mcleod, and M. J. Paape. 2001. Mammary cell number, proliferation, and apoptosis during a bovine lactation: Relation to milk production and effect of bST. J. Dairy Sci. 84:2177-2187. https://doi.org/10.3168/jds.S0022 $-0302(01) 74664-4$.

Chiba, H., M. Osanai, M. Murata, T. Kojima, and N. Sawada. 2008. Transmembrane proteins of tight junctions. Biochim. Biophys. Acta 1778:588-600. https://doi.org/10.1016/j.bbamem.2007.08 .017 .

Collier, R. J., L. L. Hernandez, and N. D. Horseman. 2012. Serotonin as a homeostatic regulator of lactation. Domest. Anim. Endocrinol. 43:161-170. https://doi.org/10.1016/j.domaniend.2012.03.006.

Dohoo, I. R., and A. H. Meek. 1982. Somatic cell counts in bovine milk. Can. Vet. J. 23:119-125.

Gross, J. J., E. C. Kessler, V. Bjerre-Harpoth, C. Dechow, C. R. Baumrucker, and R. M. Bruckmaier. 2014. Peripartal progesterone and prolactin have little effect on the rapid transport of immunoglobulin G into colostrum in dairy cows. J. Dairy Sci. 97:29232931. https://doi.org/10.3168/jds.2013-7795.

Hernandez, L. L., J. L. Collier, A. J. Vomachka, R. J. Collier, and N. D. Horseman. 2011. Suppression of lactation and acceleration of involution in the bovine mammary gland by a selective serotonin reuptake inhibitor. J. Endocrinol. 209:45-54. https://doi.org/10 $.1530 / \mathrm{JOE}-10-0452$.

Hernandez, L. L., C. M. Stiening, J. B. Wheelock, L. H. Baumgard, A. M. Parkhurst, and R. J. Collier. 2008. Evaluation of serotonin as a feedback inhibitor of lactation in the bovine. J. Dairy Sci. 91:1834-1844. https://doi.org/10.3168/jds.2007-0766.

Hernández-Castellano, L. E., L. L. Hernandez, S. Weaver, and R. M. Bruckmaier. 2017. Increased serum serotonin improves parturient calcium homeostasis in dairy cows. J. Dairy Sci. 100:1580-1587. https://doi.org/10.3168/jds.2016-11638.

Kessler, E. C., S. K. Wall, L. L. Hernandez, R. M. Bruckmaier, and J. J. Gross. 2018. Short communication: Circulating serotonin is related to the metabolic status and lactational performance at the onset of lactation in dairy cows. J. Dairy Sci. 101:11455-11460. https://doi.org/10.3168/jds.2018-14626..

Lehmann, M., O. Wellnitz, and R. M. Bruckmaier. 2013. Concomitant lipopolysaccharide-induced transfer of blood-derived components including immunoglobulins into milk. J. Dairy Sci. 96:889-896. https://doi.org/10.3168/jds.2012-5410. 
Levieux, D., and A. Ollier. 1999. Bovine immunoglobulin G, b-lactoglobulin, a-lactalbumin and serum albumin in colostrum and milk during the early postpartum period. J. Dairy Res. 66:421-430.

McFadden, T. B., R. M. Akers, and G. W. Kazmer. 1987. Alpha-lactalbumin in bovine serum: relationships with udder development and function. J. Dairy Sci. 70:259-264. https://doi.org/10.3168/ jds.S0022-0302(87)80005-X.

Mössner, R., and K.-P. Lesch. 1998. Role of serotonin in the immune system and in neuroimmune interactions. Brain Behav. Immun. 12:249-271. https://doi.org/10.1006/brbi.1998.0532.

Natzke, R. P., R. W. Everett, and D. S. Postle. 1972. Normal milk somatic cell counts. J. Milk Food Technol. 35:261-263.

Nguyen, D. A., and M. C. Neville. 1998. Tight junction regulation in the mammary gland. J. Mammary Gland Biol. Neoplasia 3:233246.

Pai, V. P., and N. D. Horseman. 2008. Biphasic regulation of mammary epithelial resistance by serotonin through activation of multiple pathways. J. Biol. Chem. 283:30901-30910. https://doi.org/ 10.1074/jbc.M802476200.

Pai, V. P., and N. D. Horseman. 2011. Multiple cellular responses to serotonin contribute to epithelial homeostasis. PLoS One 6:e17028. https://doi.org/10.1371/journal.pone.0017028.

Samarütel, J., C. R. Baumrucker, J. J. Gross, C. D. Dechow, and R. M. Bruckmaier. 2016. Quarter variation and correlations of colostrum albumin, immunoglobulin G1 and G2 in dairy cows. J. Dairy Res. 83:209-218. https://doi.org/10.1017/S0022029916000091.

Sordillo, L. M., G. A. Contreras, and S. L. Aitken. 2009. Metabolic factors affecting the inflammatory response of periparturient dairy cows. Anim. Health Res. Rev. 10:53-63. https://doi.org/10.1017/ S1466252309990016.
Sordillo, L. M., K. Shafer-Weaver, and D. DeRosa. 1997. Immunobiology of the mammary gland. J. Dairy Sci. 80:1851-1865. https:// doi.org/10.3168/jds.S0022-0302(97)76121-6.

Stelwagen, K., E. Carpenter, B. Haigh, A. Hodgkinson, and T. T. Wheeler. 2009. Immune components of bovine colostrum and milk. J. Anim. Sci. 87(Suppl):3-9. https://doi.org/10.2527/jas.2008 $-1377$.

Stelwagen, K., V. C. Farr, H. A. McFadden, C. G. Prosser, and S. R. Davis. 1997. Time course of milk accumulation-induced opening of mammary tight junctions, and blood clearance of milk components. Am. J. Physiol. 273:R379-R386. https://doi.org/10.1152/ ajpregu.1997.273.1.R379.

Stelwagen, K., I. Politis, J. H. White, B. Zavizion, C. G. Prosser, S. R Davis, and V. C. Farr. 1994. Effect of milking frequency and somatotropin on the activity of plasminogen activator, plasminogen and plasmin in bovine milk. J. Dairy Sci. 77:3577-3583. https:// doi.org/10.3168/jds.S0022-0302(94)77301-X.

Stelwagen, K., and K. Singh. 2014. The role of tight junctions in mammary gland function. J. Mammary Gland Biol. Neoplasia 19:131138. https://doi.org/10.1007/s10911-013-9309-1.

Stull, M. A., V. Pai, A. J. Vomachka, A. M. Marshall, G. A. Jacob, and N. D. Horseman. 2007. Mammary gland homeostasis employs serotonergic regulation of epithelial tight junctions. Proc. Natl. Acad. Sci. USA 104:16708-16713. https://doi.org/10.1073/pnas .0708136104 .

Wall, S. K., J. J. Gross, E. C. Kessler, K. Villez, and R. M. Bruckmaier. 2015. Blood-derived proteins in milk at start of lactation Indicators of active or passive transfer. J. Dairy Sci. 98:7748-7756. https://doi.org/10.3168/jds.2015-9440. 